\title{
The New Situation on the Korean Peninsula and China's
} Diplomatic Policy*

\author{
YUAN Xuezhe \\ Sichuan University of Science and Engineer, Zigong, China
}

\begin{abstract}
There are some positive changes on the two sides of the Korean Peninsula in 2018; the situation on the peninsula has released a signal of relaxation; it seems that the Korean Peninsula presents the "double suspension" situation which has been advocated by the Chinese government, and both the two sides of the Korean Peninsula have shown a strong will to ease the tension on the peninsula, and promote the inter-Korean relations to ease and improve the bilateral relations. As a close neighbor of the Korean Peninsula, in the face of the current situation on the peninsula, China should focus on deepening cooperation between China and the United States on the Korean nuclear issue, institutionalize the development of inter-Korean relations, and enhance its capability to resolve the Korean nuclear issue peacefully.
\end{abstract}

Keywords: inter-Korean relations, the situation on the Korean Peninsula, China's foreign diplomacy

For more than two years, the situation on the Korean Peninsula has been in a spiral of confrontation, with North Korea not only engaged in a war of words with South Korea and the United States, but also increasingly tense military preparations. However, North Korean supreme leader Kim Jong UN has repeatedly expressed his desire to improve inter-Korean relations in his 2018 New Year's message, and the situation on the Korean Peninsula has quickly shown signs of easing. Following the inter-Korean telephone talks and the decision of the United States and South Korea not to hold joint exercises during the winter Olympics, the high-level representatives of the two Koreas held face-to-face bilateral talks in Panmunjom on January 9, 2018 to discuss the DPRK's participation in the Pyeongchang Winter Olympics. On January 10, the two Koreas restarted military communication lines in the Xihai area. Since the Pyeongchang Winter Olympics, the two Koreas have restored a military hotline on the peninsula, leading to high-level talks and a consensus on holding bilateral military talks. Relations between the US and the DPRK ease after the presidential palace of the ROK issued a "five-point agreement" between the two Koreas on March 6, 2018. On March 8, the White House confirmed that U.S. President Donald trump would meet with North Korean supreme leader Kim Jong UN. On April 1, the United States and South Korea launched military exercises postponed for the Pyeongchang Winter Olympics, but they were scaled back in size and schedule, and Kim Jong UN offered a rare "understanding" of the resumption of joint drills. With the easing of inter-Korean relations, the DPRK decided on April 21 to stop its nuclear test, intercontinental ballistic missile launch test, and nuclear missile test, creating a favorable external environment for the inter-Korean summit and the relaxation of the situation on the Korean Peninsula.

\footnotetext{
* Fund: A special project of China scholarship council in 2018. No. 201808515154

YUAN Xuezhe, Ph.D., associate professor, Institute of Marxism, Sichuan University of Science and Engineer, Zigong, China.
} 
On the basis of elaborating the new situation of de-escalation on the Korean Peninsula since 2018, this paper analyzes the factors of the situation on the Korean Peninsula, explores the challenges faced by China's policy on the Korean Peninsula, and proposes China's countermeasures.

\section{A New Situation on the Korean Peninsula That Is Easing}

On April 27, 2018, North Korea's leader, Kim Jong UN, and South Korea's President in historic meeting held in constant across the military demarcation line, and in Panmunjom Korean side of the "home of peace", signed the declaration of Panmunjom, no more war, jointly announced the peninsula and the improvement of bilateral relations, peninsula to build the peaceful system to realize the denuclearization of the Korean Peninsula and reach a consensus. As far as the results of the talks are concerned, they are as follows: (1) The two sides decided to hold dialogue and consultation in various fields and hold summit talks on a regular basis to fully implement the agreement reached at the summit. It also demonstrated the special friendship between the north and the south of the Korean Peninsula as one nation. (2) De-escalate military tensions and achieve peace on the peninsula. The two sides pledged to cease all hostilities against each other, establish the demilitarized zone as a zone of peace, restart inter-Korean military dialogue, and resolve any military issues that arise. (3) Build a system of peace on the peninsula. The declaration of Panmunjom declares that there will be no more war on the peninsula. The two sides pledge not to violate each other, implement disarmament in stages according to the enhancement of mutual trust, strive to end the state of war on the peninsula within this year, and realize the transition from armistice agreement to peace mechanism.

The easing of tensions on the Korean Peninsula has reversed the tension on the peninsula since 2017 and reduced the possibility of war on the peninsula in the short term. In the long run, there are still greater risks and uncertainties. There have been unexpected situations in the history when the situation on the Korean Peninsula was eased, and it is difficult for the inter-Korean relations to get rid of the cycle of tension and easing. For more than 60 years since the armistice of the Korean War, the two Koreas have been continuously deploying heavy troops on both sides of the 38th parallel, forming a confrontation situation. The level of strategic and political mutual trust between the two Koreas is extremely low. The Korean Peninsula is located at the intersection of the strategic interests of China, the United States, Japan, Russia, and other major powers. The success of the inter-Korean summit meeting in Panmunjom laid a good foundation for the following DPRK-US dialogue, and the DPRK-US talks were also put on the agenda. U.S. President Donald trump said at a rally of supporters on April 28 that he could meet with North Korean leader Kim Jong UN in three to four weeks (CRI Online, 2018). As the key parties of the Korean Peninsula issue, the outcome of the DPRK-US talks is of vital importance. The trump administration will not abandon its policy of "extreme pressure" on North Korea, even if the United States insists on its "complete, verifiable and irreversible" denuclearization. Therefore, the differences between the US and the DPRK on the Korean nuclear issue are obvious.

\section{Analyze the Factor of the Situation on the Korean Peninsula}

The inter-Korean summit and the signing of the Panmunjom declaration show that the situation on the Korean Peninsula is moving towards peace and reconciliation. The favorable atmosphere of dialogue on the peninsula can be attributed not only to the willingness of the two sides to ease tensions and improve relations on the peninsula, but also to the joint efforts of relevant parties in the international community. 


\section{Internal Factors}

The DPRK and the ROK are major parties to the situation on the peninsula, and the inter-Korean policy interaction is an internal factor in analyzing the situation on the peninsula. From the perspective of the DPRK, its nuclear superiority and the deterioration of its domestic economic environment lead to its contact and dialogue with the US and the ROK. Kim Jong UN sanctions in the face of the international community strongly after the ruling; the North Korean nuclear guide still unswervingly promotes development process; so far, North Korea has been underway for six times test, and in the end of November 2017, North Korea announced that it had tried to launch its newly developed intercontinental llistic missile (mercury 15) and the completion of the "nuclear missile project" made the DPRK believed that it had a bargaining chip. Meanwhile, the deterioration of the economic environment within the society of the DPRK is also one of the reasons for easing the situation on the peninsula. Kim Jong UN's regime is under the harshest economic sanctions in history after the United Nations Security Council imposed new sanctions on North Korea in response to its nuclear and missile tests. North Korea had reacted furiously to sanctions after the UN Security Council adopted Resolution 2371 in August 2017. Under Resolution 2371, the sanctions target North Korea's four export industries: coal, iron and iron ore, lead and lead ore, and seafood. The resolution also bars countries from accepting new workers from North Korea. It would reduce North Korea's foreign exchange earnings by at least $\$ 1$ billion a year, or about a third of its foreign exchange earnings (Economic Information Daily, 2017). "This year is the third year of the country's five-year strategic plan for economic development. The important task of socialist economic construction this year is....To strengthen the independence and subjectivity of the national economy and improve people's lives" (Sina News, 2018). Some Chinese scholars of North Korea argue that

North Korea's interaction with the world is beginning to enter a state of complete isolation. This situation has not only dealt a heavy blow to the economy and people's livelihood, but also completely deprived the economy of the opportunity to develop. (Zhu, 2018, pp. 9-10)

North Korea is eager to establish diplomatic relations with the United States, sign a peace agreement, and obtain security guarantees, so as to achieve the purpose of providing security guarantees for the North Korean regime and easing economic sanctions.

From South Korea Level, in the beginning of the Yin government came to power; he made clear at the heart of its foreign policy goal is to achieve peace and prosperity of the Korean Peninsula; Han Guowen in Yin reflects the new government policy, and the surrounding countries actively communication, tries to dominated by native peninsula solution, and develop the civil relationship based on mutual respect, its policy with North Korea insisted on the principle of "our nation" considerable "fit". In Yin thinks, present is the best time to improve the reconciliation between north and south; he hosted in the blue house chief secretary and assistant meeting emphasized that we are faced with a peaceful solution to the Korean nuclear issue and build peninsula peace precious time, the current atmosphere of inter-Korean dialogue when can continue into the unknown, cannot blind optimistic, to keep the dialogue should be condensed wisdom and effort (Eastday News, 2018). Moon Jae-in's government aims to steer north-south relations toward reconciliation, cooperation, and independent peaceful reunification (2018, p. 23).

\section{External Factors}

The Korean Peninsula issue is a continuation of the Cold War mentality in Northeast Asia. In essence, the connotation of the Korean Peninsula has far exceeded the geographical scope of the DPRK and the ROK. The 
Korean Peninsula involves Northeast Asian countries, and China, the United States, Russia, and Japan all have important strategic interests on the Korean Peninsula. China opposes any destruction of peace in the region, and safeguard peace and stability on the Korean Peninsula is one of China's consistent position, tension in the peninsula, the situation of China put forward the "double pause" initiative and "double-track" train of thought, the bridge for the parties to realize dialogue, not only help to ease tensions on the peninsula, but also can solve the most pressing security concerns, and provide opportunities to resume peace talks, create conditions, and find out the breakthrough (Sohu, 2018). Russia has always stressed the diplomatic solution to the Korean Peninsula crisis and hopes to strengthen economic cooperation among Russia, the DPRK, and the ROK. In order to maintain peace on the peninsula, China and Russia have jointly put forward a road map to maintain peace on the peninsula. On July 4, 2017, the joint statement on the Korean Peninsula issued by the foreign ministers of China and Russia put forward a road map to solve the Korean nuclear issue. Under the joint initiative of China and Russia, the DPRK should make a voluntary political decision to suspend its nuclear test and ballistic missile test, and the US and the ROK should suspend their large-scale joint military exercises accordingly. The opposing parties have started negotiations at the same time to define the general principles of their relations, including the non-use of force, non-aggression, and peaceful coexistence. They are ready to work for the denuclearization of the Korean Peninsula and the comprehensive settlement of all issues including the nuclear issue. Russian foreign minister Sergei Lavrov said during a meeting with his Chinese counterpart Wang Yi on April 23, 2018 that all parties involved in the dialogue on the Korean Peninsula should take simultaneous measures to meet each other halfway and hope that the Korean Peninsula can be resolved in accordance with the China-Russia "road map". The diplomatic efforts of China and Russia have created a favorable external environment for easing tensions on the peninsula and resolving disputes over the peninsula issue. United Nations Security Council Resolutions 2371 and 2375, as well as U.S. sanctions against North Korea, have begun to bear fruit. U.S. secretary of state Rex Tillerson said at this time that the United States is willing to engage in unconditional dialogue with North Korea as long as it is willing to return to the negotiating table (Xinhua News Agency, 2017). Tillerson and in America's defence secretary, Matisse joint published a signed article in the Wall Street journal, said diplomacy is the preferred that promotes to change tack; peaceful pressure on North Korea's goal is to realize the denuclearization of the Korean Peninsula; America has no intention of changing the regime or accelerating the process of the two Koreas to be unified, has no intention of making excuses in the north of the DMZ garrison, and didn't mean to hurt the people (Xinhua News Agency, 2017). The United States, under increasing pressure, has signaled that diplomacy is the main measure to resolve the North Korean nuclear crisis and cool the escalating situation on the Korean Peninsula.

\section{Challenges Facing China's Policy on the Korean Peninsula}

As a close neighbor of the Korean Peninsula, China is happy to see the hard-won improvement of north-south relations and the relaxation of the situation on the peninsula. Whether the inter-Korean summit and the declaration of Panmunjom can truly open a new era of peace on the Korean Peninsula remain to be seen in the following US-DPRK talks and the future policy direction of the DPRK as well as the direction of inter-Korean and US-DPRK relations. China's security interests are at stake in the changing situation on the Korean Peninsula. At present, China's policy on the Korean Peninsula still faces many challenges, such as the Korean nuclear issue and the uncertainty of China-ROK relations. 


\section{The DPRK Nuclear Issue}

The Chinese government has always advocated denuclearization of the Korean Peninsula and opposed war and chaos on the peninsula. The Korean nuclear issue remains an important factor affecting China-DPRK relations.

China supports and actively implements the UN Security Council's economic sanctions against the DPRK, which is an important factor causing difficulties in China-DPRK relations. On the Korean nuclear issue, the DPRK's continuous nuclear and missile tests, in the final analysis, aimed at solving the issue of the DPRK's survival and development and safeguarding national sovereignty. China has always called on the international community to understand the DPRK's security concerns and adhere to the position of resolving the Korean nuclear issue through political and diplomatic channels. With the warming of the situation on the peninsula, the leaders of China and the DPRK held a "historic meeting" in late March 2018 for the first time since 2012, indicating that China-DPRK relations are entering a new stage and it is in the respective interests of the two countries to maintain friendly relations. After the US-DPRK summit meeting in Singapore, if the DPRK nuclear issue can be resolved through US-DPRK political negotiations, it is in line with the expectation of China's policy on the Korean Peninsula. China supports the US-DPRK summit talks with a view to realizing the goal of denuclearization on the Korean Peninsula.

\section{Uncertainties in China-ROK Relations}

In Northeast Asia, China and the ROK share many common interests in maintaining peace and stability in Northeast Asia and realizing common prosperity and development. China and the ROK have made new progress in policy consensus, economic and trade promotion, and people-to-people exchanges. Since the establishment of diplomatic ties, the two countries have made great achievements in cooperation in the political, economic, cultural, and other fields. Bilateral relations were once regarded as a model in the diplomatic field. But high-level talks between China and South Korea were almost completely suspended after the THAAD launch. To ease relations with China, the South Korean government has promised the "three no principles" to China. After President Moon Jae-in's state visit to China, China-South Korea relations have been gradually repaired and improved, but are full of uncertainties.

\section{China's Strategic Choice Under the New Situation}

China as the key to the Korean Peninsula peace and stability in northeast Asia countries, is the main force to promote regional cooperation, in the face of the current the situation on the peninsula; China should continue to use geopolitical advantage and strength to keep influence, in the Northeast Asia pattern of diplomacy, continue to deepen the collaboration on the Korean nuclear issue, promote the inter-Korean all-round cooperation, and improve the ability of a peaceful solution to the nuclear issue.

\section{First, Deepen Cooperation Between China and the United States on the Korean Nuclear Issue}

Peace on the Korean Peninsula is the common aspiration of all countries in Northeast Asia, and the final settlement of the Korean Peninsula issue is a systematic project involving many aspects. It not only requires the improvement of the relations between the north and the south, but also relies on the active efforts and joint progress of all stakeholders. As a signatory to the armistice agreement on the Korean War, China has always been committed to maintaining peace and stability on the Korean Peninsula and actively supports the establishment of a peace mechanism on the peninsula. Both sides need to continue coordination and 
cooperation to ensure a nuclear-free peninsula and establish a peace mechanism. China and the United States are peninsula, one of the most influential countries, both sides jointly build "six-party talks", reached the September 19 joint statement

important results, in order to solve the DPRK nuclear issue through dialogue, negotiation means laid a good foundation, to safeguard peace and stability in the peninsula has played an important role, the two countries on the denuclearization of the Korean Peninsula is still cooperation space, should continue to promote and strengthen the cooperation and coordination between China and the United States. Strengthening China-US cooperation can create conditions for timely control of the situation and change it for the better, thus contributing to the resolution of the DPRK nuclear issue. (Huang \& Cheng, 2013, p.42)

\section{Second, Institutionalize Inter-Korean Relations}

After decades of division between the two Koreas, the reason why inter-Korean relations are difficult to break out of the cycle of detente and tension is largely due to the fact that both sides are always reluctant to get rid of the zero-sum mindset. After the end of the cold war, although the north and the south joined the United Nations at the same time and inter-Korean relations have undergone many changes, both sides have never given up the goal of reunifying the other side with themselves as the main body. The level of strategic mutual trust and political mutual trust between the two sides is extremely low. It is not hard to see from the process of improving inter-Korean relations in recent days that both sides are willing to improve relations and have made some practical efforts to this end. Guarantee the stability of inter-Korean relations, never allow peninsula fighting which is on the Korean Peninsula policy goals in China, as a result, China should enhance the ability of a peaceful solution to the problem of the Korean Peninsula, with the aid of international pressure; North Korea nuclear, should get into the process of regional development, get rid of the North and South Korea a zero-sum competition thinking, institutionalization, and to promote the development of inter-Korean relations is finally solved the root of the dilemma of the Korean Peninsula.

\section{Thirdly, Enhance the Capability of Peacefully Resolving the Korean Nuclear Issue}

Under the current situation on the Korean Peninsula, China should seize the opportunity of easing the situation on the peninsula, timely adjust its policies towards the DPRK and the ROK, continue to enhance mutual trust between the two sides, maintain good communication and coordination, and at the same time skillfully balance its regional interests on the peninsula. China will continue to strengthen cooperation with the United States to improve the external security environment of the DPRK, gradually return the DPRK to the international community, and guide the DPRK to join regional cooperation in due course. China should not only safeguard the traditional friendship between China and the DPRK, but also safeguard the interests of China and the international community, respond to the sanctions imposed by the international community against the DPRK, and adhere to dialogue and consultation.

In terms of China-ROK relations, China and the ROK share common security interests in safeguarding peace and stability of the Korean Peninsula and Northeast Asia. Leaders of the two countries should conduct effective communication and coordination to enhance political mutual trust. At the same time, we will strengthen public diplomacy and enhance people-to-people friendship between China and the ROK. There are other worrying factors in the development of China-South Korea relations. For example, Chinese and South Korean citizens sometimes exaggerate the contradictions between the two countries. China must simultaneously expand its security cooperation with the United States and Japan while expanding its security 
cooperation with the republic of Korea, and should explore China's "revitalization of the Northeast China policy", the economic development of South Korea and North Korea's economic changes combined joint project, in the emerging field and financial investment, further development of China-ROK strategic cooperative partnership, work together to create conditions, with South Korea to restart the "six-party talks".

\section{Conclusion}

In a word, the Korean Peninsula is a sensitive point of China's security interests in Northeast Asia and an indispensable part of the peaceful and stable surrounding environment that China's centenary rejuvenation seeks. At present, with the improvement of inter-Korean relations and the relaxation of the situation on the Korean Peninsula, there is a historical opportunity for the summit meeting between the DPRK and the ROK and the contact between the US and the DPRK to turn into a new change in the situation on the peninsula. The direction of the situation on the Korean Peninsula depends on the substantive outcome of the US-DPRK summit and the fulfillment of the DPRK's nuclear disarmament commitment. It is in line with China's expectation that the DPRK nuclear issue will be resolved politically through negotiations. China welcomes and supports the DPRK-US summit and hopes to take this as an opportunity to construct a peace mechanism on the Korean Peninsula and realize the goal of denuclearization on the peninsula. In the future, China will be more active and steady in pursuing peace, security, and common development with the Korean Peninsula based on the long-term perspective. This will not only help safeguard national interests, but also be a positive factor for peace and development in Northeast Asia

\section{References}

Changjingwei: Pyeongchang Winter Olympics, lasting peace on the Korean Peninsula or a flash in the pan? (2018). Sohu. Retrieved from http://www.Sohu.com/a/218554981_

Huang, M. Y., \& Cheng, J. (2013). On China's strategic choice on the Korean nuclear issue. Theoretical Observation, 1(42), 42.

President Moon Jae-in of the Republic of Korea called on the Winter Olympic Games to promote inter-Korean dialogue. (2018). Eastday News. Retrieved from http://news.eastday.com/w/20180123/

Park Jianyi. (2018). The comprehensive introduction of the Moon Jae-in government's policy on North Korea. World Knowledge, $3,23$.

Trump: Could meet with Kim Jong UN in three to four weeks. (2018). CRI Online. Retrieved from http://news.cri.cn/20180429/aea1a466-2c02-242f-ef0b-f77a4e1f2328.html

The new sanctions will cost North Korea $\$ 1$ billion a year in lost revenue. (2017). Economic Information Daily. Retrieved from http://intl.ce.cn/sjjj/qy/201708/07/t20170807_24834791.shtml

The deconstruction of the geopolitical landscape on the Korean Peninsula will accelerate in 2018. (2018). Sina News. Retrieved from http://news.sina.com.cn/o/2018-01-24/doc-ifyquixe7166338.shtml

Tillerson said the United States is willing to talk to North Korea without preconditions. (2017). Xinhua News Agency. Retrieved from http://www.xinhuanet.com/mil/2017-12/13/c_129765069.htm

The US secretary of state says the US remains open to dialogue with North Korea. (2017). Xinhua News Agency. Retrieved from http://www.xinhuanet.com/mil/2017-12/13/c_129765069.htm

Zhu, F. (2018). Winter Olympics diplomacy, inter-Korean contact and US-DPRK summit talks-will there be historic new changes on the Korean Peninsula? [J]. Modern International Relations, 3, 9-10. 